International Journal of Life Sciences
Available online at http://sciencescholar.us/journal/index.php/ijls
Vol. 3 No. 3, December 2019, pages: $16 \sim 24$
e-ISSN: 2550-6986, p-ISSN: 2550-6994
https://doi.org/10.29332/ijls.v3n3.358

\title{
Overcoming the Failure of Fruit-set and Fruit Drop of Siam Orange on Off-season Period through Application of Mycorrhizal Inoculants and ZnSO4 Micro Fertilizer Dosage
}

\author{
(1) Crossiark
}

Ni Komang Alit Astiari a , Ni Putu Anom Sulistiawati b, Ida Bagus Komang Mahardika c, I Nyoman Rai ${ }^{\mathrm{d}}$

Article history: Received 27 May 2019, Accepted: 31 August 2019, Published: 11 November 2019

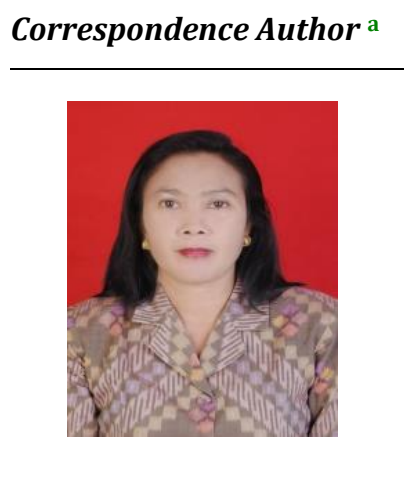

Keywords

fruit quality;

fruit-set;

micro fertilizer;

mycorrhizae;

out of season;

\begin{abstract}
This research was carried out at Kintamani District, Bangli Regency, BaliIndonesia, from February to October 2019 with aimed to overcome the failure of fruit-set and fruit drop of Siam orange on off-season period through application of mycorrhizal inoculants and $\mathrm{ZnSO}_{4}$ micro fertilizer dosage. This experiment was arranged as a randomized block design consisted of 2 factors. The first factor was mycorrhizal inoculant $(0,50,100$ and $150 \mathrm{~g} /$ tree $)$, while the second factor was the dosage of $\mathrm{ZnSO}_{4}$ micro fertilizer $(0,5,10 \mathrm{~g} /$ tree). All treatments were repeated 3 times. The results showed that the interaction between mycorrhizal inoculant treatment and $\mathrm{ZnSO}_{4}$ micro fertilizer dosage did not significantly affect all of the variables observed. Mycorrhizal inoculant dose $150 \mathrm{~g} /$ tree could overcome the failure of fruit-set and fruit drop and improved the quantity and quality of fruit of Siam oranges on off-season, which was reflected by increased number of fruits harvest per tree (249,00 fruits), weight per fruit $(106,10 \mathrm{~g})$, weight of fruit harvested per tree $(26,34 \mathrm{~kg})$ and total dissolved solids $(13.52 \%$ Brix), or increase $31,44 \%$; $18,15 \%$; $54,58 \%$; and $35,74 \%$, respectively, compared to without mycorrhizal inoculant i.e 189,44 fruit; 17,04 kg; 89,80 g and 9,96\% Brix. Treatment of $\mathrm{ZnSO}_{4}$ micro fertilizer dosage of $10 \mathrm{~g} /$ tree could also overcome the failure of fruit-set and improved the quantity and quality of fruits of Siam oranges on off-season, which was reflected by the higher number of fruit harvested per tree (233,50 fruit), weight per fruit $(100,90 \mathrm{~g})$, weight of fruit harvested per tree $(23.68 \mathrm{~kg})$ and total dissolved solids $12,83 \%$ Brix) or increase 18,88\%; 23,18\%; $23,91 \%$ dan $33,50 \%$ compared to without micronutrient of 196,42 fruits; $19,11 \mathrm{~kg} ; 81,91 \mathrm{~g}$; and $9,61 \%$ Brix.
\end{abstract}

a Warmadewa University, Denpasar, Indonesia

b Warmadewa University, Denpasar, Indonesia

c Warmadewa University, Denpasar, Indonesia

d Udayana University, Denpasar, Indonesia 
e-ISSN: 2550-6986, p-ISSN: 2550-6994@C Copyright 2019. The Author.

SS Journals Published by Universidad Técnica de Manabí.

This is an open-access article under the CC BY-SA 4.0 license

(https://creativecommons.org/licenses/by-sa/4.0/)

All rights reserved.

\section{Contents}

Abstract

1. Introduction.

2. Materials and Methods.

3. Results and Discussions

4. Conclusion

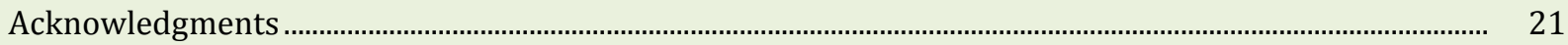

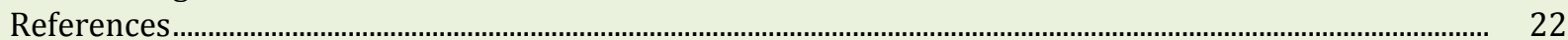

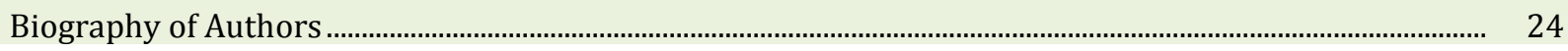

\section{Introduction}

Indonesia is a country rich in various horticultural commodities, one of them is orange. Siam orange (Citrus nobilis var. Microcarpa Hassk) is one of the most cultivated types of citrus in Indonesia and dominates $60 \%$ of the national and regional citrus markets (Dirjenhorti, 2014). Supply of this fruit commodity is seasonal, there is a lot number of fruits in the harvest season (on-season period) but there is very small supply even no supply outside the harvest season (off-season period). The situation in terms of agribusiness is not profitable. Manipulation of plants and the environment is very necessary so that fluctuations of the production can be overcome and formed balance condition between fruit supply and consumer demand from time to time.

Demand for the Siam orange fruits is very high and the price is promising, for example in traditional markets in Bali the price ranging from Rp. 10,000-15,000/kg and in supermarkets, fruit shops, hotels and restaurants, the price reaching Rp. 20,000-30,000/kg. This condition causes farmers very interest to cultivate this commodity (Astiari et al., 2018). Not only the price is expensive, but farmers also like due to its habitus small so that it can be planted with a tight planting distance with a high population per hectare. In addition, Siam orange fruit has multifunction in Balinese life, not only served as a table fruit that is enjoyed as the fresh fruit but also for processed and used as offerings in Hindu religious rituals (Suamba et al., 2014).

Naturally Siam orange flowers between November to December every year and harvesting seven to nine months after flowering (June to August). Constraints on the production of Siam orange, among others, are strongly influenced by environmental factors such as air temperature, humidity, rainfall, light intensity and plant endogenous factors (Nishikawa et al., 2013). In Bali, the cultivation of Siam orange by farmers is still traditionally with very limited production input, fertilization generally only relies on manure and irrigation only depends on rainfall. If farmers fertilize their citrus with chemical fertilizers such as $\mathrm{N}, \mathrm{P}, \mathrm{K}$, or other types of chemical fertilizers, they do it with uncertain time and dosage. As a result of such cultivation methods, Astiari et al., (2018), obtained that the condition of soil fertility of Siam oranges in Kintamani District, Bangli Regency, is very worrying, as evidenced from the levels of $\mathrm{N}, \mathrm{P}$ and $\mathrm{K}$ nutrients in the leaf tissue very low. If these conditions are ignored without adequate effort, Siam orange plantations in Bali will be increasingly miserable, so that productivity, quality, and continuity of fruit decreases over time.

One of the most prospective efforts to overcome the problems faced by farmers is by using endomycorrhizal fungi/biofertilizers. Mycorrhiza is a fungus that forms a mutualistic symbiotic relationship with plant roots. Mycorrhiza can increase nutrient absorption, especially $\mathrm{P}$, also increase resistance to drought, root pathogen attack and produce growth hormones such as cytokines, so that help plants in unfavorable soil conditions (Yadi Setiadi, 2000; Hempel et al., 2010). The association between plant roots and the mycorrhizal fungus provides very good benefits for soil and host plant where the fungus grows and reproduces (Sulistiawati et al., (2017); Kruger, 2011; Nurhandayani et al., 2013). Mycorrhiza that infects plant roots will produce hyphae intensively in the soil, spread very wide $( \pm 80 \mathrm{~mm})$ beyond the absorption area of

Astiari, N. K. A., Sulistiawati, N. P. A., Mahardika, I. B. K., \& Rai, I. N. (2019). Overcoming the failure of fruit-set and fruit drop of siam orange on off-season period through application of mycorrhizal inoculants and ZNSO4 micro fertilizer dosage. International Journal of Life Sciences, 3(3), 16-24. https://doi.org/10.29332/ijls.v3n3.358 
root hairs, so that plants can increase their capacity to absorb nutrients and water. Besides phosphorus as the main nutrient which is absorbed, mycorrhiza can also extract $\mathrm{N}, \mathrm{K}, \mathrm{S}, \mathrm{Ca}, \mathrm{Mg}, \mathrm{Zn}$ and Si (Matsubara et al., 2000; Sadhana, 2014; Tanwar et al., 2014).

The diversity of endomycorrhizal fungi, called also Arbuscular Mycorrhizal Fungi (MVA), in nature is very large (Baslam et al., 2011; Proborini et al., 2013; Suamba et al., 2014), and their application to the plants has a very positive influence (Astiari et al., 2018; Rai et al., 2014). Rai et al., (2014), showed that organic salak which was fertilized with endomycorrhizal biological fertilizer not only increased salak production but also produce off-season fruit, because it can increase soil fertility, increase photosynthesis process (reflected from increasing total sugar, reducing sugar and sucrose leaves content), and significantly increasing nutrient content of N, P, K, and Mg of leaf tissue.

Fertilization plays a very important role so that citrus plants can produce fruit well. Fertilization of Siam citrus needs to be done periodically, both using macro and micro fertilizers to increase plant growth (Khayat \& Rehiem, 2013). One of the micro fertilizers needed by plants is zinc (Zn). $\mathrm{Zn}$ is an essential microelement that acts as a co-factor of more than 300 types of enzymes, which play a role in nucleic acid metabolism, cell division, protein synthesis, for energy production, the formation of growth hormones (auxin), important for physiological balance, and stimulates growth and development of plant roots. In addition, it can improve the health and productivity of plants and increase resistance if an attack by plant disturbing organisms (Gogi $e t$ al., 2012; Sarwar, 2011; Nepolean et al., 2012). Fani et al., (2018), obtained that the highest total production of tea was obtained from the application of Zn micro fertilizer at a dose of $200 \mathrm{~kg} / \mathrm{ha}$. Sharma (2014), stated that micro fertilizer Zinc is a precursor for auxin growth hormone (IAA), which plays a role in the growth of active shoots, but zinc is not easily absorbed by plants from the soil, so spraying it through leaves is more effective.

\section{Materials and Methods}

This research was carried out at Siam citrus farm owned by farmers in Kintamani District, Bangli Regency, Bali, which began on February-Oktober 2019. This research used a factorial randomized block design with 2 treatment factors and repeated 3 times. The first factor was application of mycorrhizal inoculants, i.e $\mathrm{I}_{0}=0$ $\mathrm{g} /$ tree (control), $\mathrm{I}_{1}=50 \mathrm{~g} /$ tree, $\mathrm{I}_{2}=100 \mathrm{~g} /$ tree, and $\mathrm{I}_{3}=150 \mathrm{~g} /$ tree. While the second factor was dosage of micro fertilizer ZnSO4, i.e $\mathrm{M}_{0}=0 \mathrm{~g} /$ tree (control), $\mathrm{M}_{1}=5 \mathrm{~g} /$ tree and $\mathrm{M}_{2}=10 \mathrm{~g} /$ tree. Mycorrhizal inoculants were given one time after harvesting fruit on the period of on season through the soil, whereas $\mathrm{ZnSO} 4$ was applied twice, first when the flower formed and second when the fruit enlarged. $\mathrm{ZnSO}_{4}$ dissolved into one liter of water, then spraying to the leaves uniformly. Variables observed were number of flowers per tree, percentage of flowers into fruit/fruit-set per tree, leaf chlorophyll content, leaf $\mathrm{P}$ nutrient content, relative water content (RWC) of leaves, total sugar, reducing sugar/R-sugar and sucrose content of leaves, weight per fruit, number of fruit harvested per tree, fruit diameter, weight of fruit harvested per tree, and total dissolved solids. Data were analyzed statistically with analysis of variance according to the design used.

\section{Results and Discussions}

Interaction between mycorrhizal inoculants and the dose of micro fertilizer $\mathrm{ZnSO}_{4}$ did not significantly affect to all off observed variables. Whereas in a single factor, the application of mycorrhizal inoculants and doses of micro fertilizer $\mathrm{ZnSO}_{4}$ had a significant effect on all of the observed variables.

Application of mycorrhizal inoculants $150 \mathrm{~g} /$ tree gave the highest yield of fruit per tree $(26.34 \mathrm{~kg})$, increased of $54.58 \%$ compared to control/without mycorrhizal inoculant (17.04 kg) (Table 1). The increased weight of fruit harvested per tree at $150 \mathrm{~g}$ mycorrhizal inoculants/tree was supported by the increasing number of fruit harvested per tree, weight per fruit, and fruit diameter i.e 249.00 fruits; $106.10 \mathrm{~g}$ and $7.03 \mathrm{~cm}$, respectively, or increased of $31.14 \% ; 18.15 \%$ and $11.77 \%$ compared to control (189.44 pieces; $89.80 \mathrm{~g}$ and $6.29 \mathrm{~cm}$ ). Higher number of fruit harvested per tree was supported by the higher number of flowers formed per tree (24.89 flowers), or increase of $14.64 \%$ compared to control (257.22 flowers) The increasing number of harvested fruits per tree besides being influenced by the increasing number of flowers formed per tree also 
influenced by the higher number of flowers develop to be fruits/fruit-set. Fruit-set on treatment $150 \mathrm{~g}$ mycorrhizal inoculants/tree was $88.05 \%$, significantly higher than that of control (67.31\%) (Table 2).

Table 1

Effect of mycorrhizal inoculant and micro fertilizer $\mathrm{ZnSO}_{4}$ on the diameter of fruit, weight per fruit, number of fruits per tree, the weight of fruit per tree, and total dissolved solids

\begin{tabular}{|c|c|c|c|c|c|}
\hline Treatment & $\begin{array}{l}\text { Fruit diameter } \\
(\mathrm{cm})\end{array}$ & $\begin{array}{l}\text { Weight } \\
\text { per fruit } \\
\text { (g) }\end{array}$ & $\begin{array}{l}\text { Number of } \\
\text { fruit per tree } \\
\text { (g) }\end{array}$ & $\begin{array}{l}\text { Fruit weight } \\
\text { per tree (kg) }\end{array}$ & $\begin{array}{l}\text { Total dissolved } \\
\text { solids (\%) }\end{array}$ \\
\hline \multicolumn{6}{|c|}{ Mycorrhizal inoculants (I) } \\
\hline $\mathrm{I}_{0}\left(\begin{array}{ll}0 & \mathrm{~g} / \text { tree }\end{array}\right)$ & $6,29 \mathrm{~b}$ & $89,80 \mathrm{~b}$ & $189,44 \mathrm{c}$ & $17,04 \mathrm{c}$ & $9.96 \mathrm{c}$ \\
\hline $\mathrm{I}_{1}(50 \mathrm{~g} /$ tree $)$ & $6,35 \mathrm{~b}$ & $91,26 \mathrm{~b}$ & $210,44 \mathrm{~b}$ & $19,22 \mathrm{~b}$ & $11.40 \mathrm{~b}$ \\
\hline $\mathrm{I}_{2}(100 \mathrm{~g} /$ tree $)$ & $6,74 \mathrm{ab}$ & $101,11 \mathrm{a}$ & $242,78 \mathrm{a}$ & 24,63 a & $13.26 \mathrm{a}$ \\
\hline $\mathrm{I}_{3}(150 \mathrm{~g} /$ tree $)$ & $7.03 \mathrm{a}$ & 106,10 a & 249,00 a & 26,34 a & $13.52 \mathrm{a}$ \\
\hline LSD $5 \%$ & 0,42 & 7,18 & 14,40 & 1,80 & 0.34 \\
\hline \multicolumn{6}{|c|}{$\mathrm{ZnSO}_{4}$ Micro Fertilizers (M) } \\
\hline $\mathrm{M}_{0}(0 \mathrm{~g} /$ tree $)$ & $6.32 \mathrm{~b}$ & $81,91 \mathrm{~b}$ & $196,42 \mathrm{~b}$ & $19,11 \mathrm{~b}$ & $9.61 \mathrm{c}$ \\
\hline $\mathrm{M}_{1}(5 \mathrm{~g} /$ tree $)$ & $6,59 \mathrm{ab}$ & $98,40 \mathrm{ab}$ & 228,83 a & $22,64 \mathrm{a}$ & $12.42 \mathrm{~b}$ \\
\hline $\mathrm{M}_{2}(10 \mathrm{~g} /$ tree $)$ & $6,90 \mathrm{a}$ & $100,90 \mathrm{a}$ & $233,50 \mathrm{a}$ & $23,68 \mathrm{a}$ & $12.83 \mathrm{a}$ \\
\hline LSD $5 \%$ & 0,48 & 8,30 & 20,09 & 2,07 & 0.39 \\
\hline
\end{tabular}

Description: Number followed by the same letter in the same treatment and column means it was not significantly different at the LSD test level of $5 \%$

The higher number of fruit harvested per tree, fruit diameter, and weight per fruit at the application of mycorrhizal inoculant $150 \mathrm{~g} /$ tree compared to control closely related to higher RWC and P nutrient content of leaves (Table 2). In Table 2 it can be seen that RWC of leaves at $150 \mathrm{~g}$ mycorrhizal inoculant/tree was $89.09 \%$. It was significantly higher than control which was only $81.15 \%$. Higher RWC of leaf indicated that the application of mycorrhizal inoculants $150 \mathrm{~g} /$ tree increases the ability of plants to absorb water so that the internal water content of plant tissue increases. Increasing water absorption was followed by increasing $\mathrm{P}$ nutrient uptake, indicated by leaf P nutrient content significantly higher than that of control (Table 3). The increased RWC and P nutrient content of leaves was inseparable from mycorrhizal function. Sulistiawati et al., (2017) and Matsubara et al., (2000), stated that mycorrhiza infects plant roots will produce intensive hyphae braids in the soil and spread widely $( \pm 80 \mathrm{~mm})$ beyond the absorption area of root hairs, so plants can increase capacity to absorb nutrients, especially P and water. This was supported by the statement of Sasvari et al., (2012) and Hernadi et al.the (2014) that plants were given mycorrhizae can increase nutrient uptake especially $\mathrm{P}$ which before not available or bound by the soil to be available to plants. Therefore, mycorrhizae help absorb organic compounds that are naturally soluble for plant use, enhances photosynthesis and improve nutrient translocation in plant metabolic processes. The higher RWC of plant tissues and P nutrient of leaves, the higher the growth of plant both root and shoot growth. This condition ensuring the better process of plant metabolism, especially for transportation and photosynthate allocation so that higher crop yields. Yadi Setiadi (2000), stated that mycorrhizae can also produce growth hormones such as cytokinins. The function of cytokinin hormone can prevent the aging process and suberization of the citrus root, so root function as a water absorber and nutrients improved and it's correlated to the higher chlorophyll content of leaves. The chlorophyll content of leaves in the $150 \mathrm{~g}$ /tree mycorrhizal inoculant application was 64.30 SPAD higher than the control which was only 53.70 SPAD (Table 2). The higher leaf chlorophyll content causes the photosynthesis process to be well, which was indicated by the higher total sugar, R-sugar, sucrose content of leaves (Table 3) and total dissolved solids (Table 1). Those were correlated positively with increasing of fruit harvested per tree, the number of fruit harvested per tree, fruit diameter, and weight per fruit.

Astiari, N. K. A., Sulistiawati, N. P. A., Mahardika, I. B. K., \& Rai, I. N. (2019). Overcoming the failure of fruit-set and fruit drop of siam orange on off-season period through application of mycorrhizal inoculants and ZNSO4 micro fertilizer dosage. International Journal of Life Sciences, 3(3), 16-24. https://doi.org/10.29332/ijls.v3n3.358 
Table 2

Effect of mycorrhizal inoculant and micro fertilizer $\mathrm{ZnSO}_{4}$ on number of flowers per tree, fruit- set per tree, fruit drop per tree, leaf chlorophyll content, and RWC content

\begin{tabular}{|c|c|c|c|c|c|}
\hline Treatment & $\begin{array}{l}\text { Number of flowers } \\
\text { per tree } \\
\text { (unit) }\end{array}$ & $\begin{array}{l}\text { Fruit-set } \\
\text { per tree } \\
(\%)\end{array}$ & $\begin{array}{l}\text { Fruit drop } \\
\text { per tree } \\
(\%)\end{array}$ & $\begin{array}{l}\text { Chlorophyll } \\
\text { content of leaf } \\
(\%)\end{array}$ & $\begin{array}{l}\text { RWC of } \\
\text { leaves } \\
(\%)\end{array}$ \\
\hline \multicolumn{6}{|c|}{ Mycorrhizal inoculants (I) } \\
\hline $\mathrm{I}_{0}(0 \mathrm{~g}$ /tree $)$ & $257,22 \mathrm{~b}$ & $67,31 \mathrm{~b}$ & $26,17 \mathrm{a}$ & $53,70 \mathrm{~b}$ & $81,15 \mathrm{~d}$ \\
\hline $\mathrm{I}_{1}(50 \mathrm{~g} /$ tree $)$ & $268,44 \mathrm{~b}$ & $79,25 \mathrm{~b}$ & $17,10 \mathrm{~b}$ & $55,65 \mathrm{~b}$ & $83,33 \mathrm{c}$ \\
\hline $\mathrm{I}_{2}(100 \mathrm{~g} /$ tree $)$ & $285,89 \mathrm{a}$ & $82,61 \mathrm{~b}$ & $13,02 \mathrm{c}$ & $61,44 a$ & $86,92 \mathrm{~b}$ \\
\hline $\mathrm{I}_{3}(150 \mathrm{~g} /$ tree $)$ & $294,89 \mathrm{a}$ & $88,05 \mathrm{a}$ & $10,31 \mathrm{c}$ & $64,30 \mathrm{a}$ & $89,09 \mathrm{a}$ \\
\hline LSD $5 \%$ & 15,37 & 7,75 & 3,79 & 4,26 & 0,02 \\
\hline \multicolumn{6}{|c|}{$\mathrm{ZnSO}_{4}$ Micro Fertilizers (M) } \\
\hline $\mathrm{M}_{0}(0 \mathrm{~g} /$ tree $)$ & $253,83 \mathrm{~b}$ & $54,31 \mathrm{~b}$ & $19,64 \mathrm{a}$ & 55,79 a & $83,33 \mathrm{c}$ \\
\hline $\mathrm{M}_{1}(5 \mathrm{~g} /$ tree $)$ & $276,92 \mathrm{a}$ & $82,77 \mathrm{a}$ & $16,79 \mathrm{ab}$ & $59,26 \mathrm{ab}$ & $87,01 \mathrm{a}$ \\
\hline $\mathrm{M}_{2}(10 \mathrm{~g} /$ tree $)$ & $289,08 \mathrm{a}$ & $83,83 \mathrm{a}$ & $13,52 \mathrm{~b}$ & $61,26 \mathrm{~b}$ & $90,08 \mathrm{a}$ \\
\hline LSd $5 \%$ & 17,75 & 9,75 & 4,37 & 4,92 & 0,04 \\
\hline
\end{tabular}

Description: Number followed by the same letter in the same treatment and column means it was not significantly different at the LSD test level of $5 \%$

Table 3

Effect of mycorrhizal inoculant and micro fertilizer $\mathrm{ZnSO}_{4}$ on $\mathrm{P}$ content of leaves, total sugar, R-sugar, and sucrose content of leaves

\begin{tabular}{|c|c|c|c|c|}
\hline Treatment & $\begin{array}{l}\text { P content of } \\
\text { leaves } \\
(\%)\end{array}$ & $\begin{array}{l}\text { Total sugar } \\
\text { of leaves } \\
\text { (\%) }\end{array}$ & $\begin{array}{l}\text { R-sugar content } \\
\text { of leaves } \\
\text { (\%) }\end{array}$ & $\begin{array}{l}\text { Sucrose content } \\
\text { of leaves } \\
(\%)\end{array}$ \\
\hline \multicolumn{5}{|c|}{ Mycorrhizal inoculants (I) } \\
\hline $\mathrm{I}_{0}(0 \mathrm{~g} /$ tree $)$ & $0,11 \mathrm{c}$ & $14,59 \mathrm{~d}$ & $4,73 \mathrm{~d}$ & $9,66 \mathrm{c}$ \\
\hline $\mathrm{I}_{1}(50 \mathrm{~g} /$ tree $)$ & $0,14 \mathrm{~b}$ & $18,76 \mathrm{c}$ & $6,31 \mathrm{c}$ & $12,45 \mathrm{~b}$ \\
\hline $\mathrm{I}_{2}(100 \mathrm{~g} /$ tree $)$ & $0,16 \mathrm{~b}$ & $21,87 \mathrm{~b}$ & $8,95 \mathrm{a}$ & $12,95 \mathrm{~b}$ \\
\hline $\mathrm{I}_{3}(150 \mathrm{~g} /$ tree $)$ & $0,18 \mathrm{a}$ & 24,65 a & 9,88 a & $14,77 \mathrm{a}$ \\
\hline LSD 5\% & 0,03 & 1,17 & 0,44 & 1,64 \\
\hline \multicolumn{5}{|c|}{$\mathrm{ZnSO}_{4}$ Micro Fertilizers (M) } \\
\hline $\mathrm{M}_{0}\left(\begin{array}{l}0 \\
\mathrm{~g} / \text { tree }\end{array}\right)$ & $0,11 \mathrm{c}$ & $16,59 \mathrm{c}$ & $4,93 \mathrm{c}$ & $11,66 \mathrm{c}$ \\
\hline $\mathrm{M}_{1}(5 \mathrm{~g} /$ tree $)$ & $0,16 \mathrm{~b}$ & $21,75 \mathrm{~b}$ & $6,63 \mathrm{~b}$ & $15,12 \mathrm{~b}$ \\
\hline $\mathrm{M}_{2}(10 \mathrm{~g} /$ tree $)$ & $0,20 \mathrm{a}$ & $27,40 \mathrm{a}$ & $8,42 \mathrm{a}$ & $18,98 \mathrm{a}$ \\
\hline LSD 5\% & 0,07 & 1,20 & 0,48 & 1,73 \\
\hline
\end{tabular}

Description: Number followed by the same letter in the same treatment and column means it was not significantly different at the LSD test level of 5\%

Higher total sugar content in leaves can reduce fruit drop. The lowest percentage of fruit drop was obtained at $150 \mathrm{~g}$ mycorrhizal inoculant/tree (10,31\%) and significantly lower than that of in control (18.70\%) (Table 2). This was closely related to higher assimilate production or photosynthate supply by leaves and assimilate allocation to the fruits. The data showed that the application of mycorrhizal inoculants can be used to increase the production of Siam oranges on the off-season period because it can increase the percentage of fruit-set and number of fruit per tree and so decreased fruit drop.

On micro fertilizer $\mathrm{ZnSO}_{4}$ treatment, the highest number of fruit harvested per tree (233.50 fruits) was obtained at a dose of $10 \mathrm{~g} /$ tree or increased of $18.88 \%$ compared to control (196.42 fruits) (Table 1). The higher number of harvested fruits per tree at the dose of $10 \mathrm{~g} /$ tree caused by a significantly higher number of flowers per tree and a percentage of fruit-set. Table 1 showed that the weight of fruit harvested per tree at a 
dose of $10 \mathrm{~g} \mathrm{ZnSO}_{4} /$ tree $(23.68 \mathrm{~kg})$ significantly higher compared to control $(19.11 \mathrm{~kg})$ and it was correlated to the higher number of fruit harvested per tree, fruit diameter, and weight per fruit. The increasing number and weight of harvested fruit per tree may cause by the function of $\mathrm{Zn}$ in increasing growth and development and metabolism of plant growth. Sharma (2014) and Sarwar (2011), stated that zinc can stimulate growth and development of plant roots, increase energy production and protein synthesis, important for plant physiological balance, play a role in the formation of IAA hormones, and increase resistance to the invasion of plant organisms. Astiari et al., (2018), stated that IAA being able to stimulate root formation, play a role in the growth of active shoots, stimulate flower formation and fruit development, and prevent flowers and fruit fall down. This research has shown that the highest fruits drop was obtained at control $(19.64 \%)$ while the lowest at $10 \mathrm{~g} \mathrm{ZnSO}_{4} /$ tree $(13.52 \%)$. This means that treating Siam orange by spraying $\mathrm{ZnSO}_{4}$ can reduced fruit drop and further increase the number and weight of fruit harvested per tree.

The better number and weight of fruit harvested per tree on the application of ZnSO4 supported by higher RWC of leaves and leaf chlorophyll content. The increase of RWC and leaf chlorophyll also followed by an increase in $\mathrm{P}$ leaves content. This showed that the application of $\mathrm{ZnSO}_{4}$ fertilizer can improve water and nutrient absorb and lead to better plant metabolic processes which can increase leaf chlorophyll content. Higher leaf chlorophyll content in the treatment of $\mathrm{ZnSO}_{4}$ gave higher total sugar, R-sugar, and sucrose of leaves and total dissolved solids (Table 1 and 3). Increase total dissolved solids of the fruits in this study indicated that $\mathrm{ZnSO}_{4}$ can be used for making the fruits taste sweeter so that the quality of the fruits can be improved.

\section{Conclusion}

From this study, it can be concluded that interaction between mycorrhiza inoculant and micronutrient $\mathrm{ZnSO}_{4}$ dosage did not significantly affect to all observed variables. Mycorrhizal inoculant dose $150 \mathrm{~g} /$ tree could overcome the failure of fruit-set and fruit drop and improved the quality of the fruit of Siam oranges on the off-season period so that it can be used for producing off-season fruits. $\mathrm{ZnSO}_{4}$ micro fertilizer dosage of 10

$\mathrm{g} /$ tree can also overcome the failure of fruit-set and fruit drop and this treatment can be used for making the fruits taste sweeter so that the quality of the fruits can be improved.

\section{Acknowledgments}

The author would like to thank profusely to the Warmadewa University Research Institute, which has funded this research through Institutional Grant 2019.

Astiari, N. K. A., Sulistiawati, N. P. A., Mahardika, I. B. K., \& Rai, I. N. (2019). Overcoming the failure of fruit-set and fruit drop of siam orange on off-season period through application of mycorrhizal inoculants and ZNSO4 micro fertilizer dosage. International Journal of Life Sciences, 3(3), 16-24. https://doi.org/10.29332/ijls.v3n3.358 


\section{References}

Astiari, N. K. A., Kartini, L., Sulistiawati, N. P. A., \& Rai, I. N. (2018). Efforts to produce Siamese citrus fruit out of season and fruit quality improvement through application of potassium nitrate and agrodyke fertilizer. International journal of life sciences, 2(3), 48-58. https://doi.org/10.29332/ijls.v2n3.206

Baslam, M., Garmendia, I., \& Goicoechea, N. (2011). Arbuscular mycorrhizal fungi (AMF) improved growth and nutritional quality of greenhouse-grown lettuce. Journal of agricultural and food chemistry, 59(10), 55045515.

Dirjenhorti (Direktortat Jenderal Hortikultura). (2014). Volume dan Nilai Ekspor-Impor Hortikultura Indonesia Periode 2009-2013. Departemen Pertanian, Jakarta. http://www. hortikultura.deptan.go.id [14 Nopember 2014).

Fani, F., Regolisti, G., Delsante, M., Cantaluppi, V., Castellano, G., Gesualdo, L., ... \& Fiaccadori, E. (2018). Recent advances in the pathogenetic mechanisms of sepsis-associated acute kidney injury. Journal of nephrology, 31(3), 351-359. https://doi.org/10.1007/s40620-017-0452-4

Gogi, M. D., Arif, M. J., Muhammad, A., Bashir, M. H., Muhammad, A., Khan, M. A., ... \& Ali, A. (2012). Impact of nutrient management schedules on infestation of Bemisia tabaci on and yield of non-Bt cotton (Gossypium hirsutum) under unsprayed condition. Pakistan Entomologist, 34(1), 87-92.

Hempel, S., Renker, C., \& Buscot, F. (2007). Differences in the species composition of arbuscular mycorrhizal fungi in spore, root and soil communities in a grassland ecosystem. Environmental Microbiology, 9(8), 1930-1938. https://doi.org/10.1111/j.1462-2920.2007.01309.x

Hempel, S., Renker, C., \& Buscot, F. (2007). Differences in the species composition of arbuscular mycorrhizal fungi in spore, root and soil communities in a grassland ecosystem. Environmental Microbiology, 9(8), 1930-1938. https://doi.org/10.1111/j.1462-2920.2007.01309.x

El-Khayat, H. M., \& Abdel-Rehiem, M. A. (2013). Improving mandarin productivity and quality by using mineral and bio-fertilization. Alex. J. Agric. Res, 58(2), 141-147.

Krüger, M. (2011). Molecular phylogeny, taxonomy and evolution of arbuscular mycorrhizal fungi (Doctoral dissertation, lmu).

Matsubara, Y., Kayukawa, Y., \& Fukui, H. (2000). Temperature-stress tolerance of asparagus seedlings through symbiosis with arbuscular mycorrhizal fungus. Journal of the Japanese Society for Horticultural Science, 69(5), 570-575. https://doi.org/10.2503/jjshs.69.570

Nepolean, P., Jayanthi, R., Pallavi, R. V., Balamurugan, A., Kuberan, T., Beulah, T., \& Premkumar, R. (2012). Role of biofertilizers in increasing tea productivity. Asian Pacific Journal of Tropical Biomedicine, 2(3), S1443S1445. https://doi.org/10.1016/S2221-1691(12)60434-1

Nishikawa, F., Iwasaki, M., Fukamachi, H., Nonaka, K., Imai, A., Takishita, F., ... \& Endo, T. (2012). Fruit bearing suppresses citrus FLOWERING LOCUS T expression in vegetative shoots of satsuma mandarin (Citrus unshiu Marc.).Journal of the Japanese Society for Horticultural Science,81(1), 48-53. https://doi.org/10.2503/jjshs1.81.48

Nurhandayani, R., Linda, R., \& Khotimah, S. (2013). Inventarisasi jamur mikoriza vesikular arbuskular dari rhizosfer tanah gambut tanaman nanas (Ananas comosus (L.) Merr). Protobiont, 2(3).

Proborini, M. W., Sudana, M., Suarna, W., \& Ristiati, N. P. (2013). Indigenous vesicular arbuscular mycorrhizal (VAM) fungi in cashew nut (Anacardium occidentale L.) plantation of North East-Bali island-Indonesia.J Biol Agric Healthc, 3(3), 114-121.

Rai, I. N., Wiraatmaja, I. W., Semarajaya, C. G. A., \& Astiari, N. K. A. Upaya Memproduksi Buah Salak Gula Pasir di Luar Musim dengan Pemberian Pupuk Organik dan Mikoriza.

Sadhana, B. (2014). Arbuscular Mycorrhizal Fungi (AMF) as a Biofertilizer-a Review. Int. J. Curr. Microbiol. App. Sci, 3(4), 384-400.

Sarwar, M. (2011). Effects of Zinc fertilizer application on the incidence of rice stem borers (Scirpophaga species)(Lepidoptera: Pyralidae) in rice (Oryza sativa L.) crop. Journal of Cereals and Oilseeds, 2(1), 61-65.

Sasvári, Z., Magurno, F., Galanics, D., Hang, T. T. N., Ha, T. T. H., Luyen, N. D., \& Posta, K. (2012). Isolation and identification of arbuscular mycorrhizal fungi from agricultural fields of Vietnam. American Journal of Plant Sciences, 3(12), 1796.

Sharma, A. K., \& Sharma, A. (2014). Chromosome techniques: theory and practice. Butterworth-Heinemann. 
Suamba, I. W., Wirawan, I. G. P., \& Adiartayasa, W. (2014). Isolasi dan Identifikasi Fungi Mikoriza Arbuskular (Fma) secara Mikroskopis pada Rhizosfer Tanaman Jeruk (Citrus sp.) di Desa Kerta, Kecamatan Payangan, Kabupaten Gianyar. E-Jurnal Agroekoteknologi Tropika (Journal of Tropical Agroecotechnology).

Tanwar, A., Aggarwal, A., Kadian, N., \& Gupta, A. (2013). Arbuscular mycorrhizal inoculation and super phosphate application influence plant growth and yield of Capsicum annuum. Journal of soil science and plant nutrition, 13(1), 55-66. http://dx.doi.org/10.4067/S0718-9516201300500000

Setiadi, Y. (2000). Mycorrhizal seedling production for enhancing rehabilitation of degraded forest in Indonesia. Forest Restoration for Wildlife Conservation. International Tropical Timber Organisation and The Forest Restoration Research Unit, Chiang Mai University, Thailand, 235-243.

Sulistiawati, N. P. A., Rai, I. N., Santosa, I. G. N., \& Astarini, I. A. (2017). Flower position on main stem and branches affect fruit set in citrus plant (nobillis var, microcarpa 1). International Research Journal of Engineering, IT \& Scientific Research, 3(3), 84-92.

Astiari, N. K. A., Kartini, L., Sulistiawati, N. P. A., \& Rai, I. N. (2018). Efforts to produce Siamese citrus fruit out of season and fruit quality improvement through application of potassium nitrate and agrodyke fertilizer. International Journal of Life Sciences, 2(3), 48-58. https://doi.org/10.29332/ijls.v2n3.206

Astiari, N. K. A., Sulistiawati, N. P. A., Mahardika, I. B. K., \& Rai, I. N. (2019). Overcoming the failure of fruit-set and fruit drop of siam orange on off-season period through application of mycorrhizal inoculants and ZNSO4 micro fertilizer dosage. International Journal of Life Sciences, 3(3), 16-24. https://doi.org/10.29332/ijls.v3n3.358 


\section{Biography of Authors}

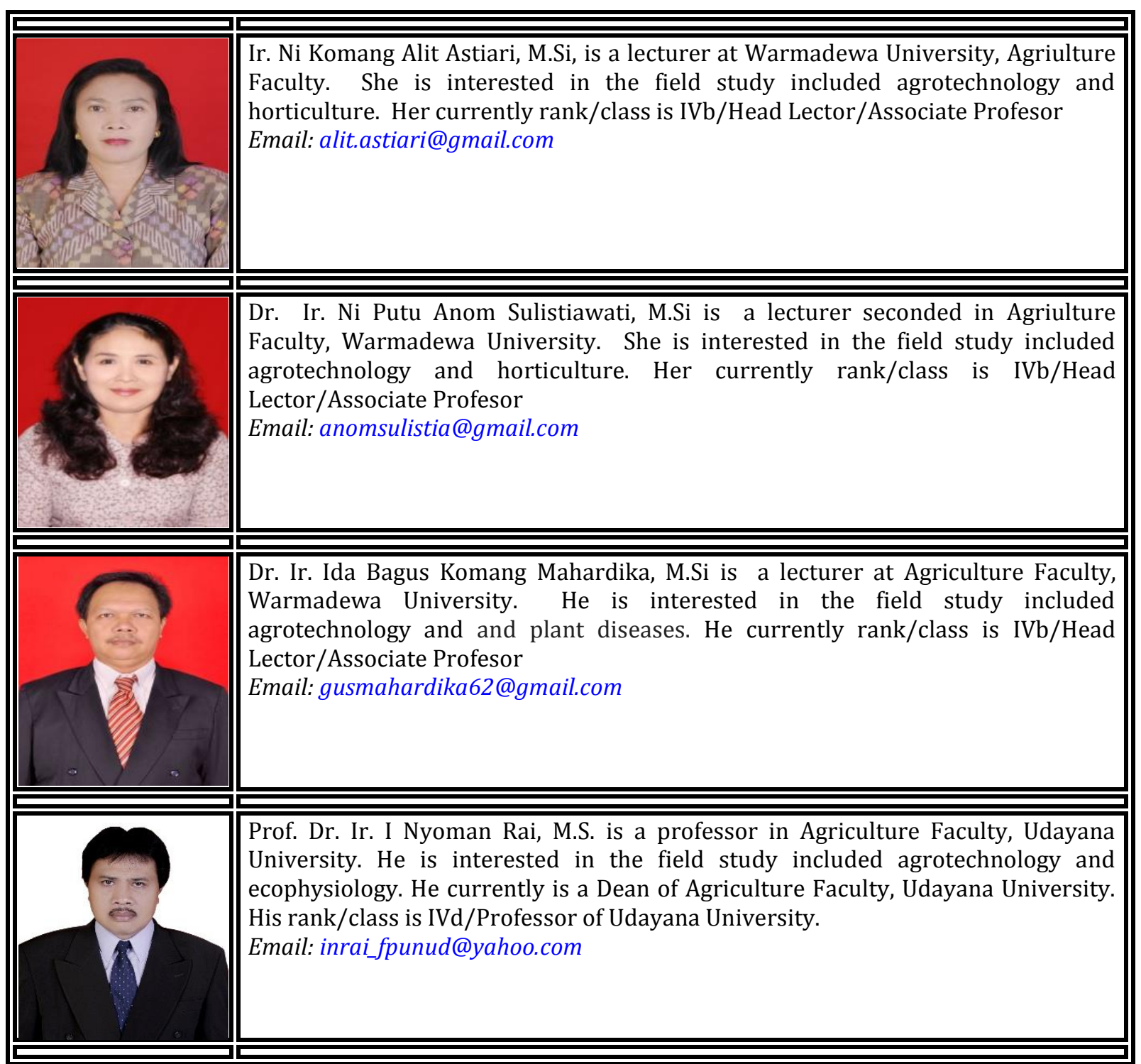

